\title{
PENGEMBANGAN SKENARIO PROBLEM BASED LEARNING (PBL) DALAM MATA PELAJARAN EKONOMI SMA
}

\author{
Syafa'atul Hidayati \\ Program Studi Pendidikan Ekonomi, Program Pascasarja \\ Universitas Negeri Malang \\ Malang, Indonesia
}

Email : syafa.iyeth@gmail.com

\begin{abstract}
Abstrak
Penelitian ini memiliki tujuan umum yaitu mengembangkan skenario Problem Based Learning (PBL) dengan pendekatan Design Based Research (DBR) dan secara rinci tujuan penelitian dan pengembangan ini, sebagai berikut: (1) mengidentifikasi permasalahan yang terjadi dalam pembelajaran ekonomi selama ini; (2) merumuskan skenario pembelajaran dengan berkolaborasi bersama tim ahli; (3) menyusun desain dan pengembangan prototipe skenario Problem Based Learning (PBL) dalam mata pelajaran ekonomi, sehingga dapat mewadahi empat tujuan dari mata pelajaran ekonomi; (4) melakukan uji coba skenario Problem Based Learning (PBL), sehingga dapat mewadahi empat tujuan dari mata pelajaran ekonomi; dan (5) mengkomunikasikan hasil uji coba skenario Problem Based Learning (PBL) kepada guru dan siswa. Secara umum penerapan penelitian berbasis desain menggunakan metode yang sistematis namun fleksibel yang bertujuan untuk meningkatkan praktik-praktik pendidikan melalui analisis iterative, desain, pengembangan dan implementasi, berdasarkan kolaborasi antara peneliti dan praktisi secara nyata tanpa adanya rekayasa.
\end{abstract}

Kata kunci : Skenario Pembelajaran, Problem Based Learning (PBL).

\begin{abstract}
Specifically, the purpose of the development research are: (1) indentifying the problems face in Economics education; (2) formulating learning scenario which collaborate with experts; (3) arranging the design and development of Problem Based Learning (PBL) scenario on Economics learning, so that it can be accommodate four objections of Economics learning; (4) Conducting Problem Based Learning $(P B L)$ scenario trial to accommodate four objections of Economics learning, and (5) delivering the findings of Problem Based Learning (PBL) scenario trial to the students and teachers. Generally, the implementation of design based research employs systematic method yet flexible in order to enhance the practical education through iterative analysis, design, development, and implementation based on collaboration of the researcher and the experts whether markedly or simulation.
\end{abstract}

Keywords: Learning Scenario, Problem Based Learning (PBL) . 


\section{PENDAHULUAN}

Menurut BSNP (2006) mata pelajaran ekonomi SMA bertujuan agar peserta didik memiliki kemampuan sebagai berikut.

1. Memahami sejumlah konsep ekonomi untuk mengkaitkan peristiwa dan masalah ekonomi dengan kehidupan sehari-hari, terutama yang terjadi dilingkungan individu, rumah tangga, masyarakat, dan negara.

2. Menampilkan sikap ingin tahu terhadap sejumlah konsep ekonomi yang diperlukan untuk mendalami ilmu ekonomi.

3. Membentuk sikap bijak, rasional dan bertanggungjawab dengan memiliki pengetahuan dan keterampilan ilmu ekonomi, manajemen, dan akuntansi yang bermanfaat bagi diri sendiri, rumah tangga, masyarakat, dan negara.

4. Membuat keputusan yang bertanggungjawab mengenai nilai-nilai sosial ekonomi dalam masyarakat yang majemuk, baik dalam skala nasional maupun internasional.

Dari tujuan diatas, seharusnya mata pelajaran ekonomi dapat mengajarkan siswa dengan pengetahuan dan keterampilan dasar agar membuat pilihan secara rasional dan menggunakan konsep-konsep dalam ilmu ekonomi untuk menganalisis persoalan-persoalan ekonomi personal dan kemasyarakatan. Model pembelajaran yang dapat mengembangkan dan mencapai tujuan mata pelajaran khususnya mata pelajaran Ekonomi SMA adalah dengan Problem Based Learning (PBL).

Dasar teoritis $\mathrm{PBL}$ telah dibangun oleh Jean Piaget, seorang psikolog Swiss. Pada dasarnya, baik Piaget maupun Vigotsky, sama-sama mengembangkan konstruktivisme psikologis. Namun demikian, Piaget lebih menekankan pada konstruktivisme psikologis yang bersifat personal, sedangkan Vigotskty lebih menekankan pada kontruktivisme psikologis yang bersifat sosial (Suparno, 1997: 43). Kedua konsep konstruktivisme tersebut menjadi landasan pokok model belajar berdasarkan masalah.

Fenomena empirik di lapangan yang diperoleh peneliti melalui wawancara kepada beberapa guru ekonomi yang ada di Malang, Banyuwangi, dan Situbondo di mana hasil wawancara tersebut menunjukkan bahwa guru khususnya guru ekonomi mengembangkan kompetensi dasar dari standar kompetensi dalam standar isi yang ada selama ini. Dalam hal ini, guru pasif dalam mengeksplorasi standar isi. Disamping itu, guru hanya fokus pada urutan pembahasan yang ada dalam buku panduan mengajar mereka. Fenomena empirik siswa masih kurang tersaji dengan baik selama proses pembelajaran. Siswa pun hanya mengetahui sejumlah konsep-konsep ekonomi yang memang sudah tersaji dalam buku. Pembelajaran lebih mengarah ke teacher centered. Hal ini pula yang tergambar dengan jelas selama observasi di SMA Laboratorium UM Malang.

Siswa menginginkan pembelajaran ekonomi yang lebih menantang bagi mereka. Di mana pembelajaran ekonomi yang dapat mengajak mereka untuk diajak berfikir menemukan dan memecahkan permasalahan ekonomi yang berkaitan dengan kehidupan mereka sehari-hari.

Dalam Permendiknas No 22 Tahun 2006, menyatakan bahwa salah satu 
Standar Kompetensi (SK) untuk mata pelajaran ekonomi kelas X adalah "memahami permasalahan ekonomi dalam kaitannya dengan kebutuhan manusia, kelangkaan dan sistem ekonomi". Kompetensi Dasarnya (KD), yaitu "mengidentifikasi kebutuhan manusia". SK dan KD tersebut sangat sesuai apabila diajarkan dengan model pembelajaran PBL. Melalui SK dan KD tersebut siswa diajak untuk memahami persoalan ekonomi di sekitar mereka dalam rangka memenuhi kebutuhannya yang bervariasi dan dihadapkan pada sumber daya yang terbatas dengan tetap memperhatikan tiga syarat kebutuhan disebut kebutuhan ekonomi, yaitu: (1) tidak dapat dihindarkan; (2) tidak gratis; dan (3) dapat dihitung. Diharapkan dengan PBL ini, pembelajaran ekonomi yang diberikan berkaitan dengan materi kebutuhan manusia lebih menantang bagi siswa untuk lebih selektif dalam melakukan pilihan rasional untuk memenuhi kebutuhannya.

Dari paparan di atas, maka perlu kiranya dikembangkan suatu skenario pembelajaran yang tepat untuk mewadahi empat tujuan dari pendidikan ekonomi. Di samping itu, juga bertujuan supaya dapat membantu siswa dalam mengatasi kesulitan-kesulitan dalam belajar materi pada mata pelajaran ekonomi. Dengan demikian peneliti tertarik untuk meneliti "Pengembangan Skenario Problem Based Learning (PBL) dalam Mata Pelajaran Ekonomi SMA."

Kajian Teori

Problem Based Learning (PBL)

Sejarah singkat Problem Based Learning (PBL)

Baden (2004: 10), menyatakan bahwa gagasan belajar melalui pemecahan masalah bukanlah hal yang baru, dan munculnya pengembangan pembelajaran berbasis masalah melalui ide sejarah dari waktu ke waktu ditandai dengan perubahan.

Pengertian Problem Based Learning (PBL)

Savery (2006) mendeskripsikan Problem Based Learning (PBL) merupakan strategi pembelajaran yang memberdayakan siswa untuk melakukan penelitian, mengintegrasikan teori dan praktik, serta mengaplikasikan pengetahuan dan keterampilan untuk mengembangkan sebuah solusi praktis atas suatu problem tertentu.

Karakteristik Problem Based Learning (PBL)

Barrows (dalam Savery : 2006), mengungkapkan karakteristik PBL adalah sebagai berikut.

a. Siswa harus mempunyai tanggung jawab sendiri.

b. Permasalahan yang diangkat dalam PBL harus bersifat ill-structured (atau belum terstruktur dengan baik), yang memungkinkan bagi inkuiri bebas.

c. Belajar seharusnya terintegrasi dari sejumlah disiplin ilmu (atau pengetahuan), atau berasal dari berbagai sumber informasi.

d. Bekerja secara kolaboratif sangat penting (untuk sharing informasi, dan ide) terkait dengan suatu permasalahan.

e. Apa yang telah siswa pelajari dalam belajar mandiri harus diaplikasikan pada permasalahan melalui reanalysis dan resolution.

f. Analisis akhir tentang apa yang telah dipelajari dari pemecahan masalah dan konsep atau teori apa yang telah dipelajari melalui diskusi, sangatlah penting.

g. Self dan peer asessment seharusnya dilakukan pada tiap akhir pemecahan masalah, atau init program PBL. 
Vol. 1, No. 1, Desember 2013

h. Aktifitas dalam PBL harus bermakna dalam kehidupan sehari-hari.

i. Ujian siswa seharusnya mengukur kemajuan siswa menuju tujuan akhir PBL.

j. PBL secara pedagogis, seharusnya mendasarkan pada kurikulum, bukan merupakan bagian kurikulum.

Proses atau tahapan Problem Based Learning (PBL)

Proses PBL menurut Davies (2002) dalam jurnalnya berikut ini.

a. The problem/task

b. First meeting

c. Research

d. Feedback meeting

e. Response

Desain masalah dalam Problem-Based Learning (PBL)

Baden (2004: 68) menyatakan bahwa ketika merancang masalah adalah penting untuk mempertimbangkan keseimbangan antara pengetahuan disiplin dan keterampilan proses seperti pemecahan masalah dan kerja sama tim.

Problem-Based Learning (PBL) dalam Mata Pelajaran Ekonomi

Mata pelajaran ekonomi berkaitan dengan cara mencari tahu tentang berbagai persoalan ekonomi yang ada dan difokuskan kepada fenomena empirik ekonomi yang ada disekitar siswa, sehingga mata pelajaran ekonomi bukan hanya penguasaan kumpulan pengetahuan yang berupa fakta-fakta, konsep-konsep, atau prinsip-prinsip saja tetapi juga merupakan suatu proses penemuan. Salah satu model pembelajaran yang dapat memberdayakan siswa adalah pembelajaran dengan model Problem Based Learning (PBL).

\section{Ekuitas - Jumal Pendidikan Ekonomi}

Pengembangan Skenario Problem Based Learning (PBL) dengan Pendekatan Design Based Research (DBR)

Pengembangan skenario pembelajaran Problem Based Learning (PBL) dalam penelitian ini menggunakan model pengembangan dengan pendekatan Design Based Research (DBR). Aplikasi riset berbasis desain untuk penyusunan dan implementasinya mengadaptasi dari model lima fase yang dikembangkan Peffers at al. (2007), seperti yang dikutip dalam Elly \& Levy (dalam Witjaksono, 2010: 112). Langkahlangkah utama dalam penelitian desain pengembangan adalah sebagai berikut: (1) identifikasi masalah; (2) merumuskan produk pengembangan; (3) desain dan pengembangan produk; (4) uji coba produk; dan (5) mengkomunikasikan hasil.

\section{METODE}

Penelitian ini dalam mengembangkan skenario Problem Based Learning (PBL) menggunakan jenis penelitian pengembangan dengan pendekatan Design Based Research (DBR), yaitu sebuah penelitian pengembangan produk berdasarkan kebutuhan yang dibutuhkan.

Prosedur Penelitian Pengembangan

Tahap pertama: mengidentifikasi kebutuhan dengan melakukan penggalian data dan diagnosis data sampai teridentifikasi masalah yang akurat. Tahap kedua: merumuskan skenario pembelajaran. Tahap ketiga: penyusunan desain dan pengembangan prototipe skenario pembelajaran. Tahap keempat: uji coba penerapan skenario Problem Based Learning (PBL) kepada siswa. Tahap kelima : komunikasi hasil uji coba skenario pembelajaran. 
Uji Coba Produk

Mengingat keterbatasan waktu, uji coba produk hanya dilaksanakan pada siswa kelas X-1 dan X-4 semester genap.

\section{Desain Uji Coba}

Beberapa kegiatan yang dilakukan meliputi: desain uji coba dilakukan pada waktu uji coba lapangan secara terbatas, Subjek Uji Coba

Subjek uji coba penelitian ini adalah siswa kelas $\mathrm{X}-1$ dan $\mathrm{X}-4$ SMA Laboratorium UM Malang. Di mana jumlah siswa kelas $\mathrm{X}-1$ sebanyak 42 dan $X-4$ berjumlah 44 siswa. Uji coba di kelas X-1 pada pelaksanaan Problem Based Learning (PBL) untuk mengetahui siswa berpotensi atau tidak dalam melakukan PBL. Sedangkan uji coba kelas X-4 dilakukan setelah produk akhir skenario PBL selesai. Pemilihan kelas X-1 dan X-4 dikarenakan kedua kelas tersebut memiliki karakteristik yang sama.

Jenis Data

Jenis data yang dikumpulkan berupa data primer yang diperoleh dari responden atau subjek uji coba yang berupa:

a. Data umum berupa hasil eksploratif dari guru dan siswa tentang pembelajaran ekonomi selama ini.

b. Hasil observasi keterlaksanaan Problem Based Learning (PBL) yang meliputi kegiatan pembelajaran oleh guru dan penilaian kinerja siswa.

c. Data khusus berupa seperangkat respon/tanggapan siswa mengenai penerapan skenario Problem Based Learning (PBL).

Instrumen Pengumpulan Data Instrumen dan teknik pengumpulan data primer dilakukan melalui:

a. Wawancara dengan guru dan siswa untuk mengumpulkan data survei awal dan analisis kebutuhan guru dan siswa terhadap skenario Problem Based Learning (PBL).

b. Wawancara dalam bentuk diskusi dengan kelompok kolaborasi dalam menyusun skenario pembelajaran.

c. Observasi untuk mengumpulkan data pelaksanaan uji coba produk dan aplikasi hasil proses pembelajaran yang diterapkan berdasarkan lembar observasi yang dibuat.

d. Kuestioner untuk tiap individu responden subjek uji coba.

Teknik Analisis Data

a. Analisis data kualitatif

Analisis data ini digunakan untuk menggambarkan data hasil wawancara untuk mengumpulkan data survei awal dan analisis kebutuhan guru dan siswa terhadap skenario Problem Based Learning (PBL) dalam kegiatan pembelajaran. Selain itu, analisis data ini juga digunakan untuk menggambarkan hasil observasi pelaksanaan uji coba produk dan aplikasi hasil proses pembelajaran yang diterapkan berdasarkan lembar observasi yang dibuat.

b. Analisis data kuantitatif

Analisis data kuantitatif digunakan peneliti untuk menggambarkan data hasil observasi pelaksanaan uji coba produk dan aplikasi hasil proses pembelajaran yang diterapkan yang meliputi kegiatan pembelajaran oleh guru dan penilaian kinerja siswa serta responden subjek uji coba.

Prosentase data dihitung dengan teknik penghitungan menurut Sugiono (2008) dan rumus berikut yang juga diterapkan oleh Wijaya (2009). 
Vol. 1, No. 1, Desember 2013

$$
\frac{\sum \text { skor yang diperoleh }}{\sum \text { skor kriteria terting i }} \times 100 \%
$$

Gambar 1. Rumus Prosentase Data

Rumus di atas adalah reduksi dari:

$$
\frac{1}{n} \times 100 \%
$$

Gambar

2. Dasar Rumus

Data

\section{HASIL DAN PEMBAHASAN}

Deskripsi Singkat Prosedur Penelitian Pengembangan

Fase pertama, yaitu peneliti melakukan identifikasi masalah. Fase kedua, merumuskan skenario Problem Based Learning (PBL). Fase ketiga, desain dan pengembangan skenario Problem Based Learning (PBL). Fase keempat, uji coba prototipe skenario Problem Based Learning (PBL). Fase kelima, komunikasi hasil uji coba pengembangan skenario Problem Based Learning (PBL).

Deskripsi Tiap Langkah Design Based Research (DBR)

Fase Identifikasi Masalah dan Assesmen Kebutuhan terhadap Skenario Problem Based Learning (PBL)

Tahap identifikasi masalah dan assesmen kebutuhan terhadap skenario PBL sebagai proses menganalisis kebutuhan guru dan siswa. Tahap ini dimulai melalui observasi awal yang dilakukan di SMA Laboratorium UM Malang dari bulan September-Oktober. Observasi diarahkan untuk mengetahui kondisi RPP yang digunakan oleh guru, karakteristik siswa, dan masalah siswa dalam pembelajaran. Berdasarkan

\section{Ekuitas - Jumal Pendidikan Ekonomi}

analisis kebutuhan guru dan siswa, belum pernah ada penelitian sebelumnya yang mengembangkan skenario PBL.

Fase Perumusan Skenario Problem Based Learning (PBL)

Pada proses perumusan awal, dimulai dengan pembuatan rancangan skenario PBL yang akan dikembangkan selama bulan Maret-April 2013.

Beberapa masukan penting dari pembimbing I dan II, antara lain: (1) skenario pembelajaran yang baik sebaiknya mengacu pada standar isi, sehingga dapat mewadahi empat tujuan dalam mata pelajaran ekonomi; (2) skenario pembelajaran sebaiknya dapat mengembangkan beberapa indikator dari Kompetensi Dasar (KD) untuk dikemas menjadi satu kali pertemuan, sehingga materi dapat diajarkan secara utuh atau tidak terpecah-pecah menjadi beberapa pertemuan; (3) skenario sebaiknya dibuat seoperasional mungkin, sehingga dapat mengarahkan guru dan membawa siswa pada kegiatan belajar merujuk pada model pembelajaran PBL; (4) dalam model PBL siswa dihadapkan kepada suatu permasalahan untuk mencari dan menemukan alternatif pemecahan masalah; (5) distribusi waktu seharusnya benar-benar diperhitungkan agar mempermudah guru dalam pengelolaan Kegiatan Belajar Mengajar (KBM); dan (6) soal-soal yang diberikan harus memuat keseluruhan materi yang diajarkan dengan model PBL.

Fase Desain dan Pengembangan Prototipe Skenario Problem Based Learning (PBL)

Fase ini merupakan aktivitas menyusun draf desain skenario PBL. Penyusunan draf desain skenario ini dengan melibatkan kelompok kolaborasi, yaitu bapak Mit Witjaksono. Proses 
Vol. 1, No. 1, Desember 2013

penyusunan skenario PBL dilakukan pertama dari pihak pengembang dari perumusan tujuan menyusun skenario meliputi: kompetensi yang diharapkan selanjutnya dikembangkan sesuai dengan teori gagne (1998), tujuan pembelajaran, materi, bentuk kegiatan pembelajaran, dan evaluasi.

Fase Uji Coba Prototipe Skenario Problem Based Learning (PBL)

1. Persiapan uji coba prototipe skenario Problem Based Learning (PBL)

a. Koordinasi pelaksanaan uji coba

b. Penyiapan siswa

2. Pelaksanaan uji coba prototipe skenario Problem Based Learning (PBL)

Maksud dan tujuan uji coba lapangan ini untuk mengetahui sejauh mana kelayakan dari produk yang dikembangkan. Adapun langkahlangkah yang ditempuh oleh peneliti adalah sebagai berikut.

a. Identifikasi dan analisis kondisi awal siswa subjek uji coba.

b. Pra tindakan, langkah ini dilakukan pada saat sebelum penelitian, yaitu pada tanggal 24 mei 2013.

c. Tindakan, yaitu pelaksanaan
pembelajaran

d. Pelaksanaan evaluasi terhadap implementasi Problem Based Learning (PBL)

Pelaksanaan evaluasi hasil belajar ini dilakukan tiga tahap, yaitu sebagai berikut.

a) Analisis kegiatan pembelajaran oleh guru

Keterlaksanaan pembelajaran oleh guru, yang bisa dilihat dari empat indikator (1) penggunaan metode; (2) ketepatan materi; (3) penguasaan materi; dan (4) penilaian dan refleksi,

\section{Ekuitas - Jumal Pendidikan Ekonomi}

sudah tercapai semua atau $100 \%$ dari deskriptor yang ada sudah terpenuhi.

b) Analisis penilaian kinerja siswa

Data prosentase hasil observasi penilaian kinerja siswa dapat diketahui bahwa kinerja kelompok I, III, VIII, dan $X$ mencapai $100 \%$. Ini artinya bahwa semua deskriptor dari indikator yang ada dapat tercapai dengan baik selama pembelajaran berlangung. Kelompok II kinerjanya sebanyak $87 \%$, kelompok IV 80\%, kelompok VI 93\%, kelompok VII 93\%, dan kelompok IX $60 \%$. Sedangkan kelompok yang kinerjanya paling rendah dibandingkan kelompok lainnya adalah kelompok $\mathrm{V}$ yang hanya $53 \%$.

c) Hasil tanggapan/respon siswa

Siswa berpendapat bahwa segi yang baik dari pelaksanaan PBL ini antara lain: (1) menambah pengetahuan tentang cara-cara baru dalam belajar yang baik; (2) siswa dituntut kreatif mencari dan menemukan sendiri materi yang dipelajari; (3) interaksi guru dan siswa tidak menakutkan; (4) materi yang disajikan langsung terkait dengan kehidupan sehari-hari yang dapat ditemukan dalam kenyataan di lapangan; (5) metode pembelajaran sangat bervariasi/tidak menoton; (6) siswa dituntut untuk lebih giat belajar; (7) tugas yang diberikan siswa lebih menantang; dan (8) pada awalnya siswa dibuat bingung/stres, tetapi begitu berlangsung pembelajaran, tidak lagi bingung, siswa sangat senang, tertarik dan puas karena ditemukan solusi terhadap masalah yang dihadapi.

Beberapa

kelemahan pelaksanaan pembelajaran ini antara lain: (1) awalnya membuat siswa 
dibuat bingung untuk memahami tugas yang dibebankan kepadanya; (2) belum terbiasa dengan format pembelajaran ini, sehingga awalnya terkesan kaku karena penyaji adalah guru baru yang belum dikenal sebelumnya oleh siswa; (3) ada beberapa siswa yang masih ramai; (4) tugas yang diberikan banyak menyita waktu; (5) terkesan siswa dibebaskan; dan (6) guru tidak menerangkan materi secara detail.

Komunikasi Hasil Uji Coba Pengembangan Skenario Problem Based Learning (PBL)

Secara keseluruhan, penelitian dan pengembangan ini telah mencapai tujuan, yaitu menghasilkan produk skenario pembelajaran berupa: (1) panduan kegiatan pembelajaran untuk fasilitator dan siswa; dan (2) bahan ajar untuk siswa. Skenario pembelajaran ini telah berhasil diujicobakan kepada siswa di SMA Laboratorium UM Malang.

\section{SIMPULAN DAN SARAN}

Kajian Produk yang Telah Direvisi

Komponen pendukung

Model yang digunakan pada produk pengembangan, yaitu belajar berbasis masalah. Karakteristik produk pengembangan pada setiap tahapan pembelajaran adalah Tahap problem/task, guru memperkenalkan masalah yang berkaitan dengan tugas yang akan dibebankan kepada siswa. Tahap firs meeting, guru membimbing siswa untuk memilih ketua kelompok dan pencatat tugas. Tahap research, guru menyediakan ringkasan materi untuk membantu siswa dalam mengerjakan tugas. Tahap feedback session, setiap anggota kelompok melaporkan kembali hasil kegiatan penelitian yang dialokasikan kepada kelompok. Dan yang terakhir adalah tahap response, guru meminta beberapa kelompok untuk melaporkan kesimpulan hasil diskusi kelompoknya di depan kelas.

Kekuatan dan Kelemahan Skenario PBL Kekuatan skenario yang telah disusun

Kekuatan dari produk skenario PBL yang dikembangkan adalah Skenario disusun untuk kepentingan siswa, sehingga strukturnya disesuaikan dengan karakteristik siswa, materi yang disajikan selama pembelajaran dapat mewadahi tujuan mata pelajaran ekonomi, skenario memuat masalah-masalah dalam kehidupan keseharian siswa yang berkaitan dengan materi yang dipelajari serta disertai dengan petunjuk dan langkahlangkah penyelesian masalah., mempertimbangkan bahwa siswa berbakat cenderung memiliki rasa ingin tahu yang sangat kuat akan banyak hal, mempunyai inisiatif dan keterampilan untuk belajar mandiri, berpikir kritis, fleksibel, dan produktif, mempertimbangkan bahwa belajar pada hakekatnya memiliki aspek sosial dan siswa berbakat harus tetap mampu belajar bersama dengan siswa lain.

Skenario yang telah disusun masih dianggap lemah karena hanya berdasarkan pada analisis masalah pembelajaran dan analisis masalah siswa dalam pembelajaran di SMA Laboratorium UM Malang. Selain itu materi yang dikembangkan hanya terbatas pada Standar Kompetensi (SK) 1, yaitu memahami permasalahan ekonomi dalam 
kaitannya dengan kebutuhan manusia, kelangkaan, dan sistem ekonomi. Kompetensi Dasar (KD) 1.1, yaitu mengidentifikasi kebutuhan manusia. Dengan judul pokok bahasan mengenai kebutuhan ekonomi. Demikian juga pada tingkat implementasi produk, skenario pembelajaran ini juga mengalami kendala, yaitu: (1) beberapa siswa tidak mau bekerja secara kelompok dengan maksimal, mereka ada yang titip nama; dan (2) beberapa siswa masih bingung dengan model PBL mengenai posisi mereka dalam pembelajaran. Disisi lain siswa merasa kekurangan waktu untuk mencari, menemukan, dan memberdayakan sumber-sumber belajar dalam rangka menemukan pemecahan masalah yang dihadapi.

Berdasarkan deskripsi kelebihan dan kelemahan skenario PBL serta temuan selama menjalankan uji coba skenario, maka berikut ini dideskripsikan beberapa saran-saran yang diharapkan dapat menjadi bahan pertimbangan dalam pengembangan produk sejenis.

Berdasarkan catatan pada saat uji lapangan yang telah dilaksanakan, maka untuk mengoptimalkan pemanfaatan skenario PBL peneliti memberikan saransaran agar alokasi waktu perlu diperhatikan, mengingat pelaksanaan PBL lebih menekankan aktivitas penyelesaian masalah yang memerlukan banyak waktu. Materi yang digunakan sebaiknya harus memperhatikan karakteristik dari model PBL. Guru secara kontinyu tetap memberikan motivasi kepada siswa, misalnya dengan memberikan latihan soal secara individu.
Guru hendaknya lebih mengenali karakteristik siswa, diantaranya latar belakang prestasi, minat studi, status sosial, status ekonomi sebagai acuan dalam membentuk kelompok belajar yang heterogen. Hal ini penting apabila PBL dilakukan secara kelompok. Guru perlu menyediakan waktu yang cukup bagi siswa untuk mencari, menemukan, dan memberdayakan sumber-sumber belajar baik yang sengaja dirancang untuk kepentingan pembelajaran (by design) maupun yang tidak sengaja dirancang tetapi diberdayakan untuk kepentingan pembelajaran (by utilization) yang sesuai dengan pilihan isi, strategi, dan waktu yang menjadi pilihannya sendiri.

Saran Pengembangan Produk lebih Lanjut

Produk pengembangan ini sudah dilakukan revisi-revisi kecil sesuai dengan saran ahli, guru mata pelajaran ekonomi, siswa, dan teman sejawat. Akan tetapi untuk lebih meningkatkan kualitas skenario, bila hendak dikembangkan lebih lanjut, sebaiknya dikembangkan untuk materi-materi lain dalam mata pelajaran ekonomi.

\section{DAFTAR RUJUKAN}

Departemen Pendidikan Nasional . 2006. Tentang Standar Kompetensi dan Kompetensi Dasar SMA/MA.

Baden, Maggi Savin. 2004. Foundation of Problem Based Learning. New York: Two Penn Plaza.

Suparno, Paul. 1997. Filsafat Konstruktivisme dalam Pendidikan. Yogyakarta: Kanisius.

Savery, John R. 2006. Overview of Problem-based Learning: 
Definitions and Distinctions, "Interdiciplinary Journal of Problembased Leraning: Vol. 1 : Iss. 1, Article $3 . \quad$ (Online), (http://docs.lib.purdue.edu/ijpbl/vol $1 /$ iss $1 / 3$.
Davies, Peter. 2002. Problem-based Learning. University of Staffordshire Sugiono, 2008. Metode Penelitian Pendidikan, Pendekatan Kualitatif, Kuantitatif, dan $R$ \& D. Bandung: Alfabeta. 